\title{
PERBANDINGAN SAHAM BERBASIS SYARIAH DENGAN SAHAM KONVENSIONAL SEBAGAI ANALISA KELAYAKAN INVESTASI BAGI INVESTOR MUSLIM
}

\begin{abstract}
The phenomenon of the lack of confidence Indonesian investors to invest more effort to control the country's wealth as his own one of them due to lack of knowledge. Including for Indonesian Muslim businessmen, is an alternative investment of choice muamalah. But in this investment activity, there are still concerns the Muslims against the perception of potential investors speculation or gharar. Therefore, the Indonesia Stock Exchange (IDX) follow up these concerns by launching Islamic products including Islamic stocks are grouped in two Islamic Indices , Jakarta Islamic Index ( JII ) in 2000 and Indonesia Sharia Stock Index (ISSI ) in 2011 . The purpose of this study is to analyze and provide empirical evidence that the rate of return and risk performance of Islamic stocks better than conventional stocks. The population is all listed companies that issued shares listed on the Indonesia Sharia Stock Index ( ISSI ) for a group of Islamic stocks and Stock Price Index (CSPI) for conventional stock group. The sampling method used was purposive sampling method in order to obtain 207 samples. Analytical techniques used include: the classical assumption of normality, descriptive statistical tests, and hypothesis testing are processed using SPSS software version 16. The results showed that there are significant differences in the performance of stocks in which the conventional stock sharia Islamic stocks have performed much better than the conventional stock.
\end{abstract}

Keywords: conventional stock, return, risk, sharia stock.

\section{PENDAHULUAN}

Berinvestasi merupakan salah satu strategi pengendalian kekayaan yang efektif bagi setiap orang. Termasuk untuk pengusaha-pengusaha muslim Indonesia, investasi adalah alternatif muamalah yang menjadi pilihan. Namun dalam kegiatan investasi ini masih terdapat kekhawatiran para calon investor muslim terhadap persepsi spekulasi atau gharar yang melekat pada sistem perdagangan di pasar modal.

Pada 12 Mei 2011 BEI meluncurkan produk layanan syariahnya berupa Indeks Saham Syariah Indonesia (ISSI) sebagai tindak lanjut dari pembentukan Daftar Efek Syariah (DES) oleh Bapepam dan LK pada Novembenr 2007. Peluncuran ISSI diperlukan sebagai pengembangan untuk menggambarkan kinerja seluruh saham syariah yang terdaftar dalam BEI. Dengan adanya ISSI masyarakat tidak lagi salah paham terhadap dimana semula pemikiran saham syariah yang dimiliki Indonesia hanya berjumlah 30 saham yang termasuk dalam Jakarta Islamic Index (JII) saja ternyata masih banyak saham syariah lainnya yang terdaftar dalam ISSI. Hal ini menjadi fenomena menarik yang membuktikan bahwa di Indonesia juga turut andil dalam mendukung kebangkitan ekonomi islam di dunia.

Kurang meratanya pemahaman dan atau pengetahuan masyarakat Indonesia tentang investasi di pasar modal yang berbasis syariah termasuk pada produk saham syariah ini bila merupakan satu fenomena yang menjadi latar belakang dalam penelitian ini pada intinya. Maka dari itu, peneliti bermaksud menyelenggarakan 
penelitian mengenai perbandingan saham berbasis syariah dengan saham konvensional sebagai analisa kelayakan investasi bagi investor muslim dengan tujuan untuk memberikan keyakinan kepada calon investor muslim di Indonesia dalam melakukan penanaman modal dengan sarana produk saham berbasis syariah. Dengan penelitian ini diharapkan investor muslim memperoleh keyakinan bahwa berinvestasi dengan saham berbasis syariah selain terhindar dari aspek spekulasi dan riba, mereka juga akan mendapatkan perolehan return yang tinggi atau minimal berbeda secara signifikan dengan investasi pada saham konvensional dengan tingkat risiko yang sesuai.

Penelitian ini merupakan pengembangan dari penelitian yang dilakukan oleh Ade Ali Nurdin (2009), Fahmi Johan Tri Marhadi (2011), dan Maya Wulan (2012). Perbedaan dengan penelitian sebelumnya terletak pada sampel yang digunakan untuk saham syariah merupakan saham-saham yang tercatat di ISSI dengan kriteria konsisten listing di ISSI sepanjang tahun 2012 sedangkan untuk saham konvensional menggunakan indeks pasar IHSG.

Perumusan masalah pada penelitian ini adalah bagaimana posisi return dan risiko dihasilkan oleh sahamsaham ISSI dibandingkan dengan indeks pasar IHSG serta apakah terdapat perbedaan signifikan yang terdapat pada return rata-rata dan risiko yang dihasilkan oleh saham-saham ISSI dengan indeks pasar IHSG.

Berdasarkan uraian diatas tujuan yang ingin dicapai dalam penelitian ini adalah memberikan bukti empiris tentang posisi return dan risiko dihasilkan oleh saham-saham ISSI dibandingkan dengan indeks pasar IHSG serta memberikan bukti empiris bahwa terdapat perbedaan signifikan yang terdapat pada return ratarata dan risiko yang dihasilkan oleh saham-saham ISSI dengan indeks pasar IHSG.

\section{KAJIAN PUSTAKA DAN PENGEMBANGAN HIPOTESIS}

\section{Saham}

Menurut Rusdin (2008) saham adalah sertifikat yang menunjukkan bukti kepemilikan suatu perusahaan, dimana pemegang saham memiliki halk klaim atas penghasilan dan aktiva perusahaan serta berhak hadir dalam Rapat UmumPemegang Saham (RUPS).

\section{Indeks Harga Saham Gabungan (IHSG)}

IHSG atau JCI (Jakarta Composite Index) pertama kali diperkenalkan pada tanggal 1 April 1983 sebagai indikator pergerakan harga saham yang tercatat di bursa, baik saham biasa maupun saham preferen. Indeks ini merupakan indikator pergerakan harga atas seluruh saham yang tercatat di BEI, di mana satuan perubahan indeks dinyatakan dalam satuan poin. Indeks Harga Saham Gabungan (IHSG) akan menunjukkan pergerakan harga saham secara umum yang tercatat di bursa efek. Indeks inilah yang paling banyak digunakan dan dipakai sebagai acuan tentang perkembangan kegiatan di pasar modal. Selain itu IHSG bisa untuk menilai situasi pasar secara umum atau mengukur apakah harga saham mengalami kenaikan atau penurunan (www.idx.co.id).

\section{Indeks Saham Syariah Indonesia (ISSI)}

Indeks saham Syariah adalah indikator yang menunjukkan kinerja/pergerakan indeks harga saham 
Syariah yang ada di Bursa Efek Indonesia (www.idx.co.id).

\section{Return Saham}

Return saham adalah pendapatan yang dinyatakan dalam persentase dari modal awal investasi. Pendapatan investasi dalam saham ini meliputi keuntungan jual beli saham dimana jika untung disebut capital gain dan jika rugi disebut capital loss. Disamping capital gain, investor juga akan menerima deviden tunai. Pembagian deviden tunai ini diputuskan dalam Rapat Umum Pemegang Saham (RUPS) atas usulan direksi perseroan (Samsul, 2006).

\section{Risiko Saham}

Risiko merupakan kemungkinan perbedaan antara return actual yang diterima dengan return yang diharapkan. Semakin besar kemungkinan perbedaanyya, berarti semakin besar risiko investasi tersebut (Sri Anik, 2006)

\section{Pengembangan Hipotesis}

\section{Posisi return rata-rata yang dihasilkan saham-saham ISSI dibandingkan dengan return pasar IHSG}

Secara konseptual, investasi dilakukan untuk memperoleh keuntungan. Sebagai investor muslim juga perlu mengetahui perbandingan dalam return dan risiko yang ditimbulkan saham syariah dengan saham konvensional agar mereka memperoleh kepuasan lebih dalam pengambilan keputusan untuk berinvestasi melalui saham syariah. Pergerakan saham syariah menunjukan prospek yang bagus setidaknya berdasarkan data Penelitian tentang kajian risk and return saham Jll dengan LQ45 menggunakan metode CAPM oleh Syarifah Farah Riessa (2006) membuktikan rata-rata return sampel Jll lebih menguntungkan dibanding ratarata return sampel LQ45.

Silvia Rahani (2009) yang melakukan penelitian analisis perbandingan kinerja portofolio optimal saham JII dengan portofolio saham Kompas100 yang dibentuk dengan Single Index Model menunjukkan kinerja portofolio optimal saham JII lebih baik dari kinerja portofolio optimal saham Kompas100. Kemudian dikemukakan oleh Kepala Biro Standar Akuntansi dan Keterbukaan Bapepam-LK, Etty Retno Wulandari dalam konferensi pers April 2012 pada periode 12 Mei 2011 - 12 April 2012, sebanyak 258 saham yang masuk ke dalam ISSI mampu meningkatkan pertumbuhan indeksnya sehingga ISSI tercatat menjadi Indeks dengan pertumbuhan tertinggi sebesar 12,72\%. Jumlah tersebut jauh melampaui pertumbuhan Indeks harga Saham Gabungan (IHSG) di periode yang sama sebesar $8,69 \%$. Sedangkan di periode yang sama, pertumbuhan 30 saham yang masuk Jakarta Islamic Index (JII) lebih tinggi dibandingkan 45 saham yang masuk Indeks LQ-4 yakni $8,47 \%$ berbanding $4,58 \%$.

Berdasarkan data dan uraian di atas maka dapat ditarik hipotesis:

\section{H1: return rata-rata yang dihasilkan saham-saham ISSI lebih tinggi dibandingkan dengan return pasar IHSG}




\section{Posisi risiko yang terjadi pada saham-saham ISSI dibandingkan dengan risiko pasar IHSG}

Penilaian dan pemahaman tentang trade-off antara risiko dan pengembalian merupakan dasar dari pencapaian kesejahteraan para investor, mengingat adanya konsep "High risk high return", yaitu semakin tinggi risiko suatu saham, maka semakin tinggi pengembalian yang ditawarkan kepada investor (Van Horne \& Wachowicz, 2005:144). Jika dalam kinerjanya, saham syariah mampu menghasilkan return yang tinggi, maka selayaknya pula risiko yang timbul juga tinggi. Inilah salah satu konsep keseimbangan dalam sistem syariah. Analisa rate of return dengan model Capital Asset Pricing Model (CAPM) juga mengasumsikan return suatu sekuritas berbanding lurus dengan risikonya. Sementara kendala yang dihadapi dalam investasi saham syariah adalah konsep bagi hasil yang tidak mampu memberikan patokan tingkat penghasilan yang pasti. Instrumen investasi syariah masih terbatas ditambah pula diversifikasi investasi syariah yang terbatas jelas akan menyulitkan pengelola dana. Oleh karena itu, investasi syariah mempunyai risiko yang lebih tinggi.

Dari kerangka pemikiran tersebut, maka ditarik hipotesis :

\section{H2: Risiko yang terjadi pada saham-saham ISSI lebih tinggi dibandingkan dengan risiko pasar IHSG}

\section{Perbandingan terhadap return rata-rata dan risiko yang dihasilkan oleh saham-saham ISSI dengan indeks pasar IHSG}

Secara umum perbedaan nilai indeks saham syariah dengan nilai indeks saham konvensional terletak pada kriteria saham emiten yang harus memenuhi prinsip-prinsip dasar syariah. Sedangkan secara konsep antara keduanya tidak jauh berbeda. Ketertarikan investor pada saham yang terdapat dalam Jll juga disebabkan oleh return yang menarik dan fluktuasinya tidak berbeda jauh dengan indeks LQ45. Hal ini mengingat beberapa saham yang terdapat pada JII merupakan konstituen indeks LQ45 juga. Hal ini dibuktikan oleh Fahmi, Johan Tri Marhadi (2011) dengan penelitiannya "Analisis Perbandingan Risk And Return Saham Syariah dengan Saham Konvensional (Studi pada Saham LQ 45 dan Jakarta Islamic Index di Bursa Efek Indonesia Periode 2005 2008 )" menunjukkan tidak ada perbedaan yang signifikan terhadap risiko saham LQ 45 dengan JII dan tidak ada perbedaan yang signifikan terhadap return saham LQ 45 dan JII. Dan penelitian serupa juga ditemukan diluar Indonesia dengan sampel yang berbeda yaitu Dharani dan Natarajan (2011) secara empiris meneliti risiko dan pengembalian dari Nifty Sharia Index dan Nifty Index yang kemudian menyimpulkan bahwa Syariah Nifty Index dan Nifty Index di India memiliki hasil kinerja yang sama. Kali ini peneliti dalam penelitian ini akan melakukan pengujian terhadap sampel yang berbeda yaitu menggunakan data dari Indeks Saham Syariah Indonesia (ISSI) yang berdasarkan sepengetahuan peneliti merupakan produk yang masih tergolong baru dan belum banyak digunakan peneliti sebelumnya.

Hipotesis yang dapat ditarik dari kerangka di atas adalah :

\section{H3: tidak terdapat perbedaan signifikan antara return rata-rata dan risiko yang dihasilkan oleh saham- saham ISSI dengan indeks pasar IHSG}




\section{METODE PENELITIAN}

\section{Jenis Penelitian}

Jenis penelitian ini adalah penelitian deskriptif kuantitatif. Penelitian kuantitatif menekankan pada pengujian teori-teori melalui pengukuran variabel-variabel penelitian dengan angka dan melakukan analisis data dengan prosedur statistik.

\section{Populasi dan Sampel}

Pada penelitian ini populasi yang digunakan adalah seluruh emiten yang menerbitkan saham yang terdaftar pada Indeks Saham Syariah Indonesia (ISSI) untuk kelompok saham syariah dan Indeks Harga Saham Gabungan (IHSG) untuk kelompok saham konvensional. Metode pengambilan sampel yang digunakan adalah metode purposive sampling, dimana populasi yang akan dijadikan sampel penelitian adalah populasi yang memenuhi kriteria sampel tertentu.

\section{Teknik Analisis}

Data yang digunakan dalam penelitian ini dianalisis dengan menggunakan metode analisis deskriptif dengan menggunakan alat bantu berupa perangkat lunak statistik yang dikenal dengan SPSS. Sedangkan teknik analisis yang digunakan meliputi : uji asumsi klasik normalitas, uji statistik deskriptif, dan uji hipotesis.

\section{Uji Normalitas}

Adapun untuk kriteria pengujian dengan uji statistik Kolmogrov Smirnov test adalah: $\mathrm{Ha}=$ data residual tidak berdistribusi normal. Apabila nilai signifikansi kolmogrov smirnov test adalah lebih kecil dari 0,05 maka Ha diterima, sehingga data residual tidak berdistribusi normal. Sebaliknya, apabila nilai signifikansi lebih besar dari 0,05 maka Ha ditolak, sehingga data residual berdistribusi normal.

\section{Uji Statistik Deskriptif}

Statistik deskriptif digunakan untuk memberikan gambaran variabel-variabel yang diteliti. Uji statistik deskriptif mencakup range, nilai minimum, nilai maksimum, nilai rata-rata (mean), serta standar deviasi dari data return dan risiko yang telah dihoitung untuk periode Januari-Desember 2012.

\section{Uji Hipotesis}

Untuk membandingkan antara return dan risiko saham syariah dengan saham konvensional maka digunakan alat analisis uji beda untuk one sample $t$ test. Perbandingan tersebut dilakukan dengan tahapantahapan sebagai berikut: a) Dilakukan perhitungan karakteristik keuangan untuk mengetahui tingkat return dan risiko pada setiap saham dalam kedua indeks saham (ISSI dan IHSG). b) Dilakukan uji hipotesis, yaitu uji beda t test.

Setelah uji t dilakukan, selanjutnya dilakukan uji signifikansi dengan membandingkan hasil uji t dengan t tabel berdasarkan tingkat kepercayaan $95 \%$ (alpha $5 \%$ ). Jika nilai -t tabel >t hitung atau t hitung >t tabel, 
maka hipotesis nol $\mathrm{(Ho}$ ) diterima dan hipotesis alternatif $\mathrm{(Ha}$ ) ditolak. Artinya, tidak terdapat perbedaan yang signifikan dari varibel yang diukur. Sebaliknya, jika nilai -t table>t hitung atau t hitung $>\mathrm{t}$ tabel, maka Ho ditolak dan Ha diterima. Ini berarti bahwa terdapat perbedaan yang signifikan. Penarikan kesimpulan juga bisa dilakukan dengan membandingkan nilai signifikansi (Sig.) pengujian dengan alpha 5\%. Jika Nilai signifikansi lebih kecil dari 5\%, maka Ho ditolak, dan jika Nilai Signifikansi lebih besar dari 5\%, maka Ho diterima. Pengujian hipotesis menggunakan uji beda dibantu dengan menggunakan SPSS.

\section{HASIL DAN PEMBAHASAN}

\section{Deskripsi Sampel Penelitian}

Populasi dalam penelitian ini adalah seluruh emiten yang menerbitkan saham yang terdaftar pada Indeks Saham Syariah Indonesia (ISSI) untuk kelompok saham syariah dan Indeks Harga Saham Gabungan (IHSG) untuk kelompok saham konvensional. Berdasarkan data yang dikumpulkan diperoleh 207 emiten terdaftar sebagai sampel.

Seleksi Sampel Penelitian

\begin{tabular}{|l|c|}
\hline Keterangan & Jumlah \\
\hline Jumlah saham terdaftar issi per 22 desember 2011 & 237 \\
\hline Saham keluar 1 juni 2012 & 20 \\
\hline Saham keluar 27 juni 2012 & 1 \\
\hline Saham keluar 22 november 2012 & 6 \\
\hline Sampel yang tidak memenuhi data yang dibutuhkan & 3 \\
\hline Jumlah saham terdaftar per 1 Jan-31 Des 2012 & $\mathbf{2 0 7}$ \\
\hline
\end{tabular}

\section{Analisis Data}

\section{Uji Normalitas}

Sebelum melakukan pengujian lebih lanjut, pertama kali dilakukan pengujian terhadap normalitas data yang dilakukan dengan menggunakan metode one sample kolmogorov smirnov (1-Sample K-S). Pada pengujian ini jika nilai signifikansi Kolmogorov-Smirnov lebih besar dari 0,05, maka data residual terdistribusi normal. Sebaliknya jika signifikansi Kolmogorov-Smirnov lebih kecil dari 0,05 maka data residual terdistribusi secara tidak normal (Ghozali, 2005).

Hasil uji normalitas data menunjukkan bahwa nilai Kolmogorov-Smirnov Z sebesar 1,132 dengan tingkat signifikansi 0,154 atas data return saham dan 1,263 dengan tingkat signifikansi 0,082 atas data risiko saham. Berdasarkan hasil tersebut, nilai Asymp. Signifikansi masing-masing data lebih besar dari 0.05 maka data penelitian ini terdistribusi secara normal.

\section{Uji Statistik Deskriptif}

Penelitian ini menggunakan uji statistik deskriptif untuk memberikan gambaran terhadap return dan risiko. Dimana penelitian dilakukan pada periode tahun 2012, dengan sampel 207 perusahaan yang konsisten terdaftar dalam Indeks Saham Syariah Indonesia (ISSI) tahun 2012. Setelah dilakukan perhitungan untuk nilai return dan risiko saham pada periode pengamatan maka dapat diketahui range, nilai minimum, nilai 
maksimum, mean, dan standar deviasi dari perusahaan tersebut pada analisis statistik deskriptif.

Dari hasil output spss diketahui bahwa nilai return dan risiko selama periode pengamatan memiliki nilai minimum -64,40 dan -0,00. Sedangkan nilai maksimumnya adalah 1.129,36 dan 239,46. Dari nilai minimum dan maksimum tersebut diperoleh range untuk data return dan risiko sebesar 1.193,76 dan 239,46. Angka return yang bernilai positif menunjukkan bahwa saham pada tahun tersebut memiliki harga lebih tinggi dari harga sebelumnya sedangkan nilai negatif menunjukkan bahwa saham pada tahun tersebut memiliki harga lebih rendah dari harga sebelumnya.

\section{Uji Hipotesis}

Pengujian selanjutnya adalah uji beda T-test yang dilakukan untuk mengetahui perbandingan tingkat return dan risiko saham-saham ISSI dengan IHSG. Hipotesis yang diajukan menyatakan bahwa rata-rata tingkat return dan risiko saham-saham ISSI lebih tinggi dibandingkan dengan nilai pasar IHSG.

Untuk mengetahui kebenaran hipotesis tersebut, maka dilakukan Uji Beda T-Test terhadap tingkat return dan risiko saham-saham ISSI dengan IHSG. Pada tabel One-Sample Statistics menunjukkan rata-rata return saham-saham ISSI dan risikonya adalah 44,8250 dan 14,3860. Berdasarkan hasil rata-rata tersebut menunjukkan tingkat return dan risiko saham-saham ISSI lebih tinggi dibandingkan dengan rata-rata return dan risiko sahamsaham konvensional yang diwakili nilai return dan risiko IHSG sebesar 12,94 dan 3,53.

Pada tabel one sample test menunjukkan nilai t hitung return saham sebesar 3,615 dengan tingkat signifikansi 0,000 dan nilai t hitung risiko saham sebesar 7,965 dengan tingkat signifikansi 0,000. Karena sig kedua data tersebut < 0.05 maka dapat disimpulkan bahwa Ho ditolak dan Ha diterima. Artinya terdapat perbedaan signifikan antara return dan risiko saham-saham ISSI dengan IHSG.

\section{KESIMPULAN, KETERBATASAN DAN SARAN}

Berdasarkan hasil penelitian dapat disimpulkan bahwa terdapat perbedaan yang signifikan pada kinerja saham syariah dengan saham konvensional. Hasil pengujian empiris menunjukkan bahwa rata-rata tingkat return dan risiko Indeks Harga Saham Gabungan (IHSG) lebih rendah daripada tingkat return dan risiko Indeks Saham Syariah Indonesia (ISSI).

Hal ini membuktikan bahwa saham syariah memiliki kinerja yang lebih baik dibandingkan saham konvensional. Penelitian dilakukan menggunakan data sekunder pada periode tahun 2012. Return tertinggi tahun 2012 sebesar 1.129,36\% diperoleh pada saham Centrin Online Tbk. dengan risiko sebesar 37,49\%. Sedangkan return terendah sebesar -64,40\% diperoleh saham Sorini Agro Asia Corporindo Tbk. dengan risiko 0,00\%. Saham-saham tersebut merupakan saham yang terdaftar pada Indeks Saham Syariah Indonesia (ISSI) dan memenuhi kriteria konsisten listing selama periode tahun 2012. Perhitungan return dan risiko sahamsaham individual menggunakan rasio closing price atau harga penutupan saham bulanan dan tahunan periode tahun 2012. 


\section{Keterbatasan Penelitian}

Penelitian ini hanya menggunakan data pengamatan selama satu tahun mengingat masih barunya Indeks Saham Syariah Indonesia (ISSI) diluncurkan oleh Bursa Efek Indonesia (BEI) , merupakan jangka waktu yang singkat untuk suatu penelitian.

Penelitian ini bertujuan sebagai informasi untuk mengetahui kelayakan investasi saham syariah hanya meneliti berdasarkan tingkat kinerja return dan risiko, sedangkan kelayakan investasi juga dapat diteliti melalui studi terhadap diversifikasi produk investasi untuk mengurangi resiko, meminimalkan resiko, kemudahan pencairan investasi, transparan dalam pelaporan, pengelolaan oleh manajer investasi yang professional dan biaya investasi yang rendah.

\section{Saran}

Berdasarkan kesimpulan di atas, investor dan calon investor yang melakukan investasi pada saham yang termasuk dalam Indeks Saham Syariah (ISSI) sebaiknya mengantisipasi keadaan di pasar sebelum membeli saham-saham tersebut. Adanya informasi-informasi tentang kebijakan pemerintah yang baru sangat memungkinkan mempengaruhi harga sekuritas-sekuritas di pasar modal. Sehingga dengan adanya penilitian ini dapat dijadikan referensi investor dan calon investor agar mengetahui sebelum menentukan keputusan dalam berinvestasi. Dalam hal ini disarankan untuk memilih saham syariah terutama yang termasuk dalam Indeks Saham Syariah (ISSI) karena selain meberikan hasil kinerja yang baik, para investor juga memperoleh kenyamanan dalam bermualah secara syariah.

Bagi penelitian lain sebaiknya melakukan penelitian pembanding, dengan variabel yang berbeda pada periode yang sama ataupun dengan variabel yang sama pada periode yang berbeda. Misalnya pengujian terhadap perbandingan saham syariah dengan saham konvensional berdasarkan nilai indeks saham dan volume trading pada periode 2011-2013.

Jurnal Akuntansi Indonesia 
Anik, Sri. 2006. Teori Portofolio dan Analisis Investasi. Semarang: Unissula Press.

Dharani dan Natarajan, 2012. Shariah Compliant Stocks In India- A Viable And Ethical Investment Vehicle. India:Arabian Journal of Business and Management Review (OMAN Chapter) Vol. 1, No.6; January 2012.

Fitriani, Maya Wulan. 2012. Skripsi. Judul: "Analisis Perbandingan Risk dan Return Antara Saham Syariah Dengan Saham Konvensional (Studi Pada Saham JII Dan LQ45 Pada Sektor Industri Barang Konsumsi)Universitas Islam Negeri Maulana Malik Ibrahim . Malang: Digital Library UIN.

(http://lib.uin-malang.ac.id/?mod=th detail\&id=08510151)

Ghozali, Imam. 2005. Aplikasi Analisis Multivariate dengan Program SPSS. Semarang: Badan Penerbit Universitas Diponegoro.

http://www.idx.co.id

http://www.bapepam.go.id

$h t t p: / / w w w . f i n a n c e . y a h o o . c o m$

James C, Van Horne \& Jhon M. Wachowicz, JR. 2005. Fundamental Of Financial Management/Prinsip-Prinsip Manajemen Keuangan. Edisi 12. Jakarta: Salemba Empat.

Johan Tri Marhadi, Fahmi. 2011. Tesis. Analisis Perbandingan Risk And Return Saham Syariah dengan Saham Konvensional (Studipada Saham LQ 45 dan Jakarta Islamic Index di Bursa Efek Indonesia Periode 2005 2008 ). Fakultas IImu Administrasi Universitas Brawijaya Malang.

Nurdin, Ade Ali. 2009. Perbandingan Kinerja Portofolio Optimal Saham-Saham Unggulan Berbasis Syariah dengan Saham-Saham Unggulan Berbasis Konvensional Di Bursa Efek Indonesia. Jurnal Ekonomi, Keuangan, Perbankan dan Akuntansi Vol. 1, No. 2, November. pp 173-188.

Rahani, Silvia. 2009. Skripsi. Analisis Perbandingan Kinerja Portofolio Optimal Saham Jii (Jakarta Islamic Index) Dengan Kinerja Portofolio Optimal Saham Kompas 100 Yang Dibentuk Melalui Single Index Model Periode Tahun 2008-2009. Fakultas Ekonomi dan Bisnis Universitas Padjadjaran.

Rusdin. 2008. Pasar Modal: Teori, Masalah, dan Kebijakan dalam Praktik. Bandung: Alfabeta.

Samsul, Mohamad. 2006. Pasar Modal dan Manajemen Portofolio. Jakarta: Erlangga. 


\section{LAMPIRAN}

Model Penelitian

Model Penelitian

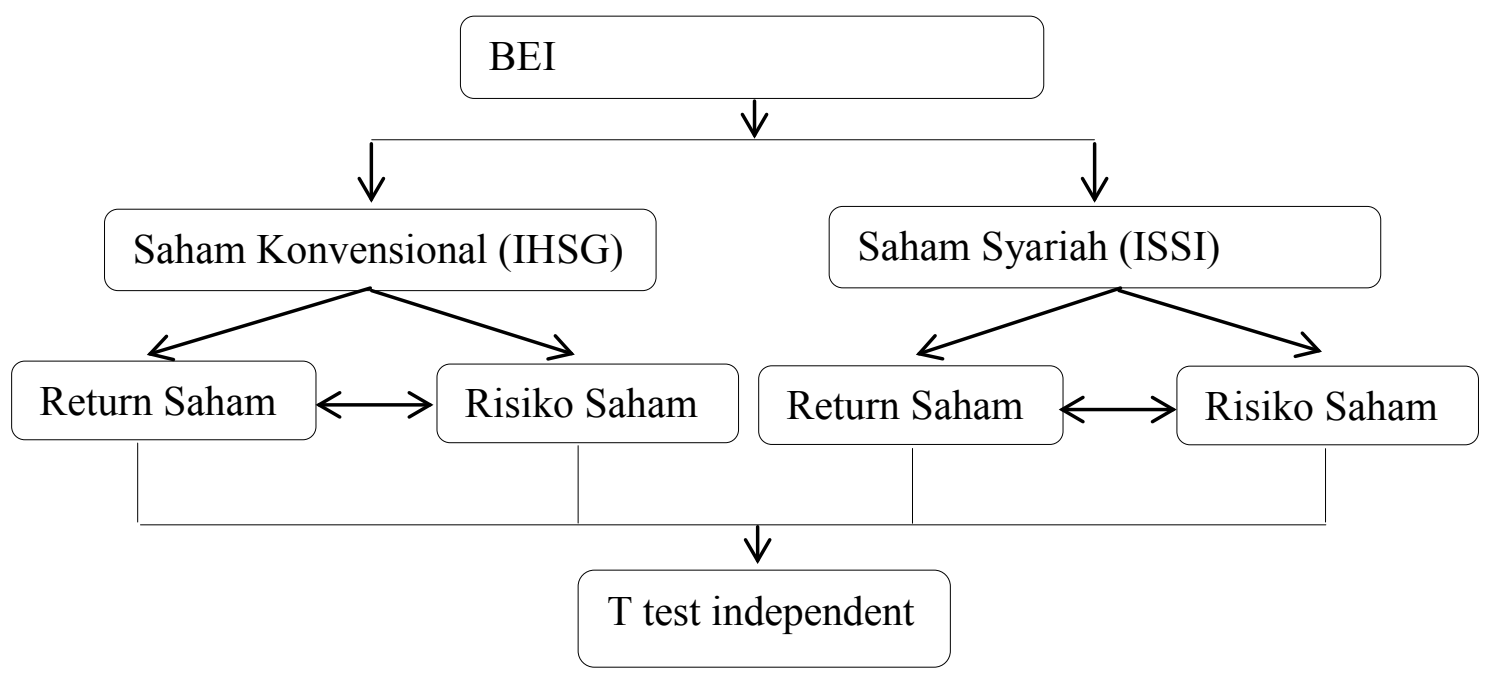

Uji Normalitas Data Return

Hasil Uji Normalitas Data Return

One-Sample Kolmogorov-Smirnov Test

\begin{tabular}{llc}
\hline & & \multicolumn{2}{c}{ Logreturn } \\
\hline \multirow{2}{*}{ Normal Parameters ${ }^{\mathrm{a}}$} & $\mathrm{N}$ & 126 \\
\cline { 2 - 3 } & Mean & 1.6066 \\
\cline { 2 - 3 } Most Extreme Differences & Std. Deviation & .53775 \\
\cline { 2 - 3 } & Positive & .101 \\
\cline { 2 - 3 } & Negative & .057 \\
\hline Kolmogorov-Smirnov Z & & -.101 \\
\hline Asymp. Sig. (2-tailed) & & 1.132 \\
\hline
\end{tabular}

a. Test distribution is Normal. 


\section{Hasil Uji Normalita Data Risiko}

One-Sample Kolmogorov-Smirnov Test

\begin{tabular}{llc}
\hline & $\mathrm{N}$ & \multicolumn{2}{c}{ Logrisiko } \\
\hline \multirow{2}{*}{ Normal Parameters ${ }^{\mathrm{a}}$} & Mean & 1.0536 \\
\cline { 2 - 3 } & Std. Deviation & .28079 \\
\hline \multirow{2}{*}{ Most Extreme Differences } & Absolute & .089 \\
\cline { 2 - 3 } & Positive & .089 \\
\cline { 2 - 3 } & Negative & -.064 \\
\hline Kolmogorov-Smirnov Z & & 1.263 \\
\hline Asymp. Sig. (2-tailed) & & .082 \\
\hline
\end{tabular}

a. Test distribution is Normal.

Sumber : Output SPSS

\section{Hasil Uji Statistik Deskriptif Return dan Risiko}

Descriptive Statistics

\begin{tabular}{lcccccc} 
& N & Range & Minimum & Maximum & Mean & $\begin{array}{c}\text { Std. } \\
\text { Deviation }\end{array}$ \\
\hline return saham & 207 & $1.193,76$ & $-64,40$ & $1.129,36$ & 44,9407 & 126,85003 \\
\hline risiko saham & 207 & 239,46 &, 00 & 239,46 & 14,3860 & 19,61018 \\
\hline Valid N (listwise) & 207 & & & & & \\
\hline
\end{tabular}

Sumber: Output SPSS

Hasil Uji Hipotesis One Sample T-Test Return Saham

One-Sample Statistics

\begin{tabular}{ccccc} 
& $\mathrm{N}$ & Mean & Std. Deviation & Std. Error Mean \\
\hline return saham & 207 & 44,8250 & 126,89117 & 8,81955 \\
\hline
\end{tabular}

One-Sample Test

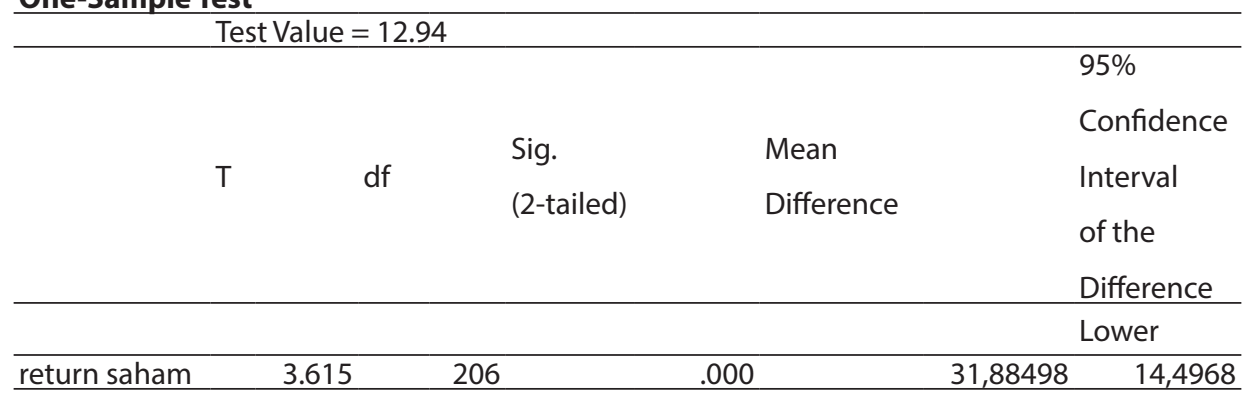

Sumber: Output SPSS 
JURNAL AKUNTANSI INDONESIA

Hasil Uji Hipotesis One Sample T-Test Risiko Saham

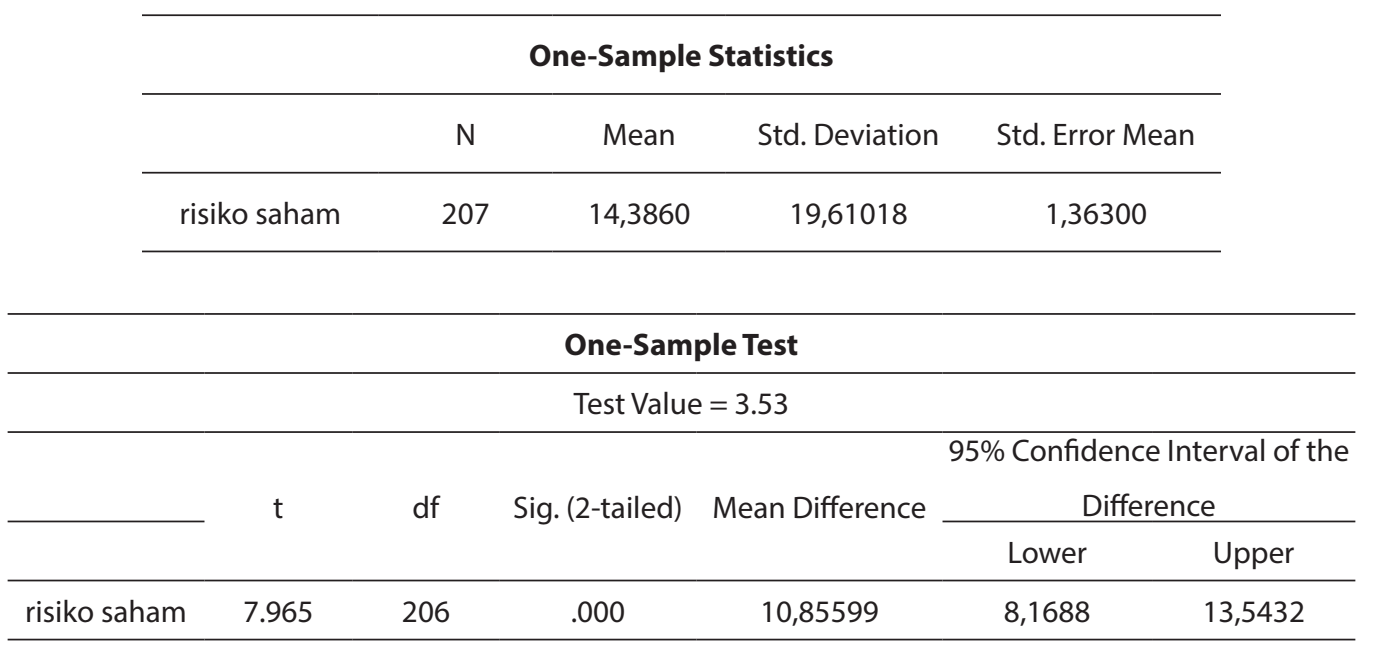

Sumber : Output SPSS

Jurnal Akuntansi Indonesia 